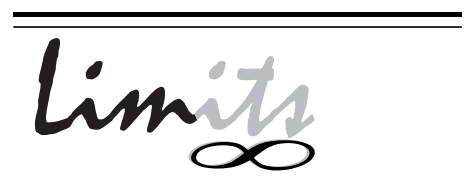

J. Math. and Its Appl.

ISSN : $1829-605 \mathrm{X}$

Vol. 6, No. 1, May 2009, 35-50

\title{
DESAIN KONTROL POSISI PADA PANEL SURYA DENGAN MENGGUNAKAN METODE FUZZY SLIDING MODE CONTROL (FSMC)
}

\author{
Mardlijah $^{1}$, Wawan Ismanto ${ }^{2}$, I Gst Ngr Rai Usadha ${ }^{3}$ \\ ${ }^{1}$ Jurusan Matematika, FMIPA ITS Surabaya \\ ${ }^{1}$ mardlijah@yahoo.com
}

\begin{abstract}
Abstrak
Salah satu energi alternatif yang banyak kita miliki untuk mengatasi masalah kelangkaan energi adalah panel surya. Dalam rangka pengoptimalan penggunaan panel surya itu, diperlukan sebuah sistem pengendali yang dapat mengontrol posisi panel surya agar selalu mengikuti arah dan posisi dari matahari. Hal ini dilakukan karena energi surya diserap secara maksimal pada saat posisi tegak lurus.

Ada beberapa macam sistem pengendali yang sudah digunakan untuk mengontrol posisi panel surya diantaranya Proporsional Integrator dan Differensiator (PID), Sliding Mode Control (SMC) dan Fuzzy Logic Control (FLC). Dalam makalah ini dibahas penggunaan metode Fuzzy Sliding Mode Control (FSMC) pada pengendalian posisi panel surya agar selalu dalam posisi tegak lurus. FSMC merupakan kombinasi dari SMC dan FLC. Modifikasi dan kombinasi pada SMC dan FLC menghasilkan performansi sistem yang lebih baik. Hal ini terlihat pada hasil simulasi yang sudah dilakukan.
\end{abstract}

Katakunci: Panel Surya, Sliding Mode Control (SMC), Fuzzy Logic Control (FLC), Fuzzy Sliding Mode Control (FSMC) 


\section{Pendahuluan}

Indonesia yang memiliki banyak potensi energi terbarukan, seperti tenaga air (termasuk minihidro), panas bumi, biomasa, angin dan surya (matahari) yang bersih dan ramah lingkungan, yang belum dapat dimanfaatkan secara optimal. Belum optimalnya pemanfaatan energi terbarukan disebabkan biaya pembangkitan pembangkit listrik energi terbarukan, seperti tenaga surya, tidak dapat bersaing dengan biaya pembangkitan pembangkit listrik berbahan bakar energi fosil (bahan bakar minyak, gas bumi, dan batubara). Hal ini terjadi, karena intensitas panas yang diterima oleh permukaan bumi adalah relatif kecil, sehingga memerlukan kolektor (pengumpul) yang cukup luas untuk keperluan pembangkitannya.

Pada makalah ini, posisi dari bagian kolektor (pengumpul) sinar matahari diatur sedemikian rupa sehingga diharapkan akan selalu tepat dengan arah matahari pada siang hari [3]. Hal ini dikarenakan karena matahari sebagai sumber energi dari panel surya bersifat tidak tetap pada hanya satu posisi. Oleh karena itu diperlukan sebuah sistem pengendali yang dapat mengontrol posisi panel surya agar selalu mengikuti arah dan posisi dari matahari, sehingga dapat menyerap sel surya secara maksimal.

Dalam rangka memenuhi kebutuhan pengendali yang dapat bekerja dengan baik, maka digunakan pengendali Sliding Mode Control (SMC) pada penelitian sebelumnya. Pengendali SMC memiliki beberapa kelebihan jika dibandingkan dengan pengendali PID, yaitu sifatnya yang sangat robust, mampu bekerja dengan baik pada sistem nonlinear yang memiliki ketidakpastian model ataupun parameter. Namun demikian, pengendali SMC masih memiliki kekurangan, yaitu sedikit lebih rumit dalam perancangannya daripada pengendali PID dan masih adanya error meskipun terhitung kecil saat terjadi perubahan parameter berupa penurunan nilai parameter [1].

Konsep Fuzzy Logic Control (FLC) terbukti efektif menghadapi sistem nonlinear yang kompleks dengan ketidakpastian yang sulit untuk dimodelkan [9]. Pengendali FLC merupakan pengendali yang mudah dan sederhana untuk dirancang, tetapi juga memiliki beberapa kelemahan, diantaranya adalah keterbatasan analisis maupun sintesis terhadap metode ini. Untuk memperbaiki performansi sistem, SMC murni dimodifikasi dan dikombinasikan dengan konsep FLC sehingga hasil modifikasi ini disebut Fuzzy Sliding 
Mode Control (FSMC) [8].

Pada makalah ini, akan dirancang suatu sistem kontrol posisi pada panel surya dengan menggunakan metode FSMC untuk memperoleh sistem pengendali alternatif yang dapat bekerja dengan baik pada sistem nonlinear yang kontinu dengan ketidakpastian yang besar.

\section{Sistem Panel Surya}

Model sistem kontrol posisi pada sistem panel surya secara sederhana seperti terlihat pada Gambar 1 [2] di bawah ini. Prinsip kerja dari sistem ini

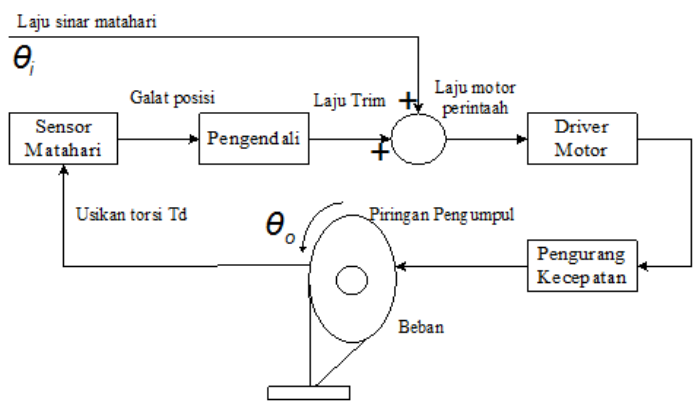

Gambar 1: Diagram skematik sistem panel surya

adalah bagaimana mengatur posisi dari piringan pengumpul sinar matahari agar selalu mengikuti posisi matahari sehingga permukaan piring pengumpul matahari selalu dalam kondisi tegak lurus dengan arah sinar matahari karena mempertahankan sinar matahari jatuh ke sebuah permukaan panel secara tegak lurus akan mendapatkan energi maksimum $\pm 1000 \mathrm{~W} / \mathrm{m} 2$ atau $1 \mathrm{~kW} / \mathrm{m} 2$ [3].

Sistem ini merupakan sistem dengan satu masukan dan satu keluaran dengan objek yang dikendalikan adalah motor servo DC [4].

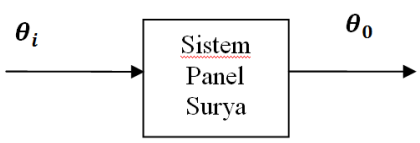

Gambar 2: Diagram blok masukan dan keluaran sistem panel surya 
Masukan sistem adalah laju sinar matahari $\left(\theta_{i}\right)$ yang diterima oleh dua sensor sel photovoltaic silikon persegi yang diletakkan sedemikian rupa sehingga pada saat sensor diarahkan ke matahari, sinar cahaya dari celah melingkari kedua sel tersebut [2]. Sedangkan keluaran sistem adalah posisi sudut dari motor $\left(\theta_{0}\right)$ yang digunakan untuk menggerakkan kolektor sehingga berputar mengikuti arah posisi matahari.

Matahari adalah objek dari panel surya, jadi panel surya harus dapat mengikuti arah gerak dari matahari agar efisiensi dari panel surya menjadi maksimal. Dan untuk dapat memposisikan panel surya agar selalu tegak lurus dengan matahari dibutuhkan panel surya yang dapat dikendalikan. Pemodelan dilakukan dengan menurunkan persamaan matematis dari bagian - bagian penyusun yang merupakana penggerak dari panel surya. Dari

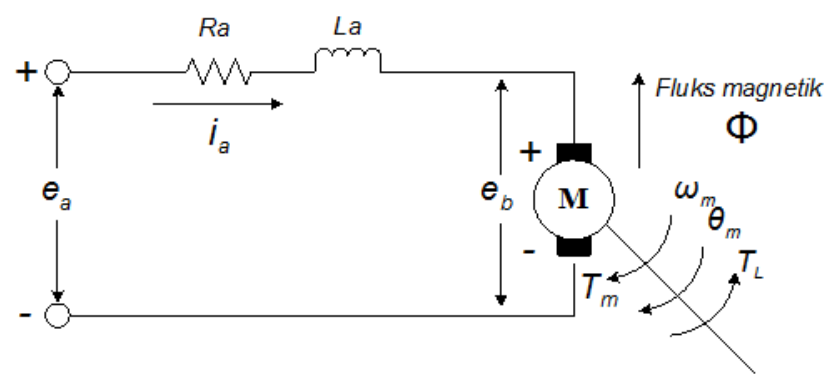

Gambar 3: Model motor servo DC

Gambar 3 diperoleh :

$$
e_{a}(t)=R_{a} i_{a}(t)+L_{a} \frac{d i_{a}(t)}{d t}+e_{b}(t)
$$

dengan

$$
\begin{aligned}
e_{b}(t) & =K_{b} \omega_{m}(t) \\
T_{m}(t) & =K_{m} i_{a}(t) \\
T_{m}(t) & =J \frac{d \omega_{m}(t)}{d t}+B \omega_{m}(t)
\end{aligned}
$$


dengan

$$
\begin{aligned}
e_{a}(t) & : \text { Besarnya tegangan yang diberikan pada motor (volt) } \\
e_{b}(t) & : \text { emf balik (volt) } \\
i_{a}(t) & : \text { Arus jangkar (Ampere) } \\
R_{a}(t) & : \text { Tahanan kumparan jangkar }(\mathrm{Ohm}) \\
L_{a}(t) & : \text { Induktansi kumparan jangkar }(\mathrm{Henry}) \\
K_{b} & : \text { Konstanta emf balik (Volt-sec/rad) } \\
K_{m} & : \text { Konstanta torsi (N-m/Ampere) } \\
J & : \text { Momen inersia rotor }(\mathrm{Kg}-\mathrm{m} 2) \\
B & : \text { Koefisien gesekan viskos }(\mathrm{N}-\mathrm{m} / \mathrm{rad} / \mathrm{sec}) \\
T_{m}(t) & : \text { Torsi motor (N-m) } \\
\omega_{m}(t) & : \text { Kecepatan sudut motor }(\mathrm{rad} / \mathrm{sec})
\end{aligned}
$$

Salah satu bagian dari sistem kontrol posisi adalah penguat servo (amplifier servo). Secara sederhana, keluaran amplifier servo dapat dinyatakan

$$
e_{a}(t)=-K\left[e_{o}(t)+e_{t}(t)\right]=-K e_{s}(t)
$$

dengan :

$e_{a}$ : Tegangan keluaran servo amplifier (Volt)

$K$ : Besarnya nilai penguatan

$e_{0}$ : Tegangan masukan dari takometer (Volt)

$e_{t}$ : Tegangan masukan dari penguat amplifier, op-amp (Volt)

$e_{s}$ : Jumlahan tegangan masukan pada servo amplifier (Volt)

Untuk mendeteksi kecepatan sudut dari motor digunakan takometer. Keluaran takometer dalam bentuk tegangan (et) diumpan balikkan melalui konstanta takometer $K t$. Secara matematis, hubungan ini dapat ditulis :

$$
e_{t}(t)=K_{t} \omega_{m}(t)
$$

dengan :

et : Tegangan keluaran takometer (Volt)

$K t$ : Konstanta takometer 
$\omega m:$ Kecepatan sudut motor $(\mathrm{rad} / \mathrm{sec})$

Roda gigi berfungsi sebagai pengurang kecepatan sudut dari motor. Secara mekanik, sumbu dari motor dihubungkan dengan roda gigi, sehingga posisi sudut roda gigi keluaran dihubungkan ke posisi motor melalui perbandingan roda gigi $1 / n$, sehingga :

$$
\theta_{0}=\frac{1}{n} \theta_{m}
$$

dengan :

$\theta_{0}$ : posisi sudut keluaran roda gigi.

$\theta_{m}$ : posisi sudut motor.

\section{Sistem Pengendali Fuzzy Sliding Mode Control (FSMC)}

Untuk memperbaiki performansi sistem pengendali SMC, dilakukan modifikasi pada SMC dengan menggunakan FLC. Modifikasi ini umumnya disebut sebagai fuzzy sliding mode control (FSMC) atau sliding mode fuzzy logic control (SMFLC) [8][10].

Perancangan pengendali FSMC lebih sederhana daripada merancang pengendali SMC, terutama dalam hal menentukan besarnya control input u. Karena pada FSMC, besarnya $u$ diperoleh dari aturan fuzzy dengan bentuk $R_{C}^{i}$ : Jika $s=L_{S_{i}}$ dan $d=L D_{i}$ maka $u=L U_{i}$ dimana $s$ adalah jarak antara vektor keadaan dan permukaan sliding, dan $d$ adalah jarak antara vektor keadaan dan vektor normal ke permukaan sliding dimana vektor normal melalui titik asal dari ruang keadaan. $L S_{i} \in T S$ dan $L D_{i} \in T D$ masing - masing adalah nilai fuzzy dari variabel keadaan fuzzy $s$ dan $d$ pada daerah fuzzy ke- $i$ dari ruang keadaan fuzzy. $L U_{i}$ adalah vektor masukan fuzzy yang berkorespondensi pada daerah fuzzy ke- $i$ dari ruang keadaan fuzzy. TS, TD dan TU adalah himpunan dari $s, d$ dan $u$ yang mencakup range dari nilai fuzzy $s, d$ dan $u$. Gambar 4 menunjukkan interpretasi grafis $s_{p}$ dan $d$ pada bidang $e \dot{e}$, dimana $s_{p}$ menunjukkan jarak antara titik keadaan dan permukaan sliding. $d$ menunjukkan jarak antara titik keadaan dan garis normal dari permukaan sliding yang melalui titik asal bidang ee 


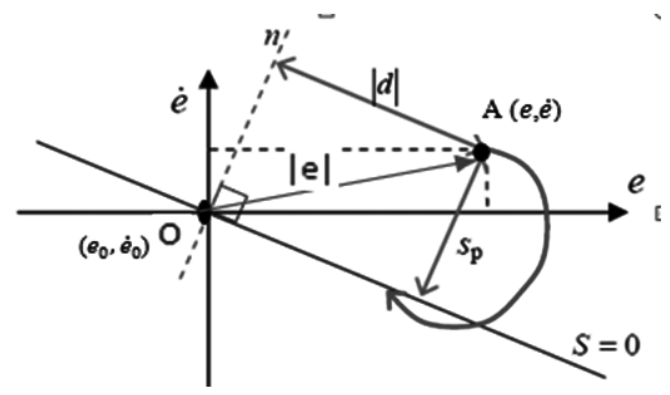

Gambar 4: Interpretasi grafis dari $s_{p}$ dan $d[6]$

Dengan demikian $s_{p}$ dan $d$ dapat dinyatakan dengan persamaan :

$$
\begin{gathered}
S_{p}=\frac{|\dot{e}+\lambda e|}{\sqrt{1+\lambda^{2}}} \\
d=\sqrt{|e|^{2}-S_{p}^{2}}
\end{gathered}
$$

dengan aturan fuzzy untuk FSMC dapat dinyatakan oleh Tabel 1

Tabel 1 Aturan umum fuzzy untuk pengendali FSMC [6]

\begin{tabular}{|l|l|l|l|l|l|l|l|l|l|}
\hline & & \multicolumn{6}{|l|}{$S_{p}$} \\
\hline & & NB & NM & NS & NZ & PZ & PS & PM & PB \\
\hline$d$ & B & PB & PB & PB & PB & NB & NB & NB & NB \\
\hline & M & PB & PB & PB & PM & NM & NB & NB & NB \\
\hline & S & PB & PB & PM & PS & NS & NM & NB & NB \\
\hline & Z & PB & PM & PS & PZ & NZ & NS & NM & NB \\
\hline
\end{tabular}

\section{Perancangan Sistem Pengendali}

Model matematika pada sistem posisi panel surya didapatkan dengan menggabungkan atau mensubstitusikan rumusan - rumusan yang ada dalam komponen - komponen panel surya, sehingga diperoleh :

$$
\ddot{\omega}=C u-D_{1} \omega-D_{2} \dot{\omega}+d
$$


Dengan mengasumsikan,

$$
\begin{aligned}
e_{a}(t) & =u \\
C & =\frac{K_{m}}{L_{a} J} \\
D_{1} & =\frac{R_{a} B+K_{b} K_{m}}{L_{a} J} \\
D_{2} & =\frac{R_{a} J+L_{a} B}{L_{a} J}
\end{aligned}
$$

Pada perancangan pengendali FSMC diperlukan suatu fungsi switching $S$ sebagai berikut [7]:

$$
S=\dot{e}+\lambda e
$$

dengan

$$
\begin{aligned}
& e=\omega-\omega_{d} \\
& \dot{e}=\dot{\omega}-\dot{\omega}_{d}
\end{aligned}
$$

Permukaan slidingnya adalah :

$$
\dot{e}+\lambda e=0
$$

Penentuan nilai control input $u$ pada FSMC menggunakan dua variabel masukan pada fuzzy, yaitu $s_{p}$ dan $d$. Oleh karena itu, ditentukan fungsi keanggotaan dari $s_{p}$ dan $d$ dengan aturan fuzzynya. Pada penentuan fungsi keanggotaan, perlu diketahui batasan nilai $s_{p}$ dan $d$. Hal ini dapat dilihat dari lup terbuka system panel surya, dengan nilai $\omega$ dan $\dot{\omega}$ sebagai berikut:

$$
\omega \in[-0.000073,0.000073], \dot{\omega} \in[-0.0027,0.0027]
$$

Dari data tersebut dicari nilai maksimum dari $s_{p}$ dan $d$ dengan nilai $\lambda=$ 10.

$$
\begin{gathered}
S_{p}=\frac{|\dot{\omega}+\lambda \omega|}{\sqrt{1+\lambda^{2}}}=\frac{|0.0027+10 .(0.000073)|}{\sqrt{1+10^{2}}}=0.000341297 \\
d=\sqrt{|e|^{2}-S_{p}^{2}}=\sqrt{\left((0.000073)^{2}+(0.0027)^{2}\right)-0^{2}}=0.002700986
\end{gathered}
$$

Dengan memperbesar range nilai $s_{p}$ dan $d$, diperoleh intervalnya yaitu :

$$
S_{p} \in[-0.00034,0.00034], d \in[0,0.0027]
$$




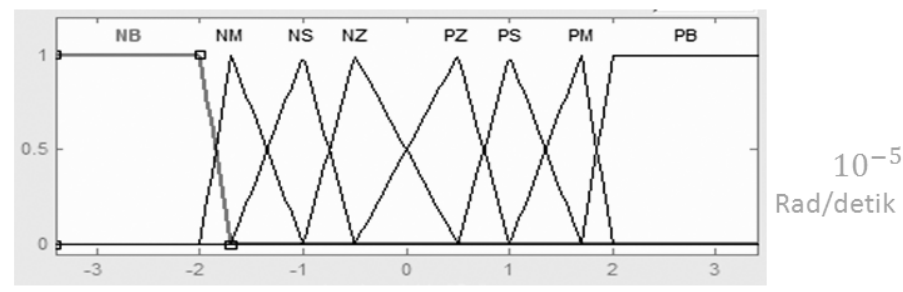

Gambar 5: Fungsi keanggotaan $S_{p}$ pada pengendali FSMC

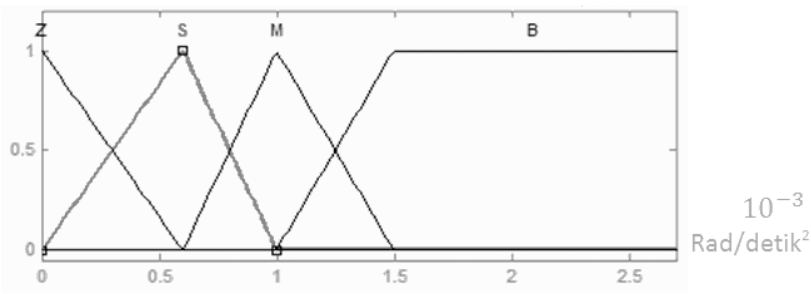

Gambar 6: Fungsi keanggotaan $d$ pada pengendali FSMC

Setelah diketahui masing - masing variabel, selanjutnya dirancang fungsi keanggotaannya dari $s_{p}$ dan $d$ seperti ditunjukkan oleh Gambar 5 dan 6 . Nilai control input $u$ diambil dengan rentang yang sama dengan perancangan FLC, namun dengan pembagian interval tiap fungsi keanggotaan yang berbeda, yang ditunjukkan oleh Gambar 7. Aturan fuzzy yang digunakan pada pengendali FSMC yang mengacu pada Tabel 1.

Setelah diperoleh rancangan fungsi keanggotaan dan aturan fuzzy, langkah berikutnya adalah mengimplementasikan diagram blok dan rancangan fuzzy pada matlab. Hasil perancangan pengendali FSMC pada simulink dapat dilihat pada Gambar 8, dimana rangkaian system berupa system lup tertutup dengan umpan balik. Supaya dapat dibandingkan dengan hasil pengendalian SMC, pada pengendalian FSMC ini digunakan $\lambda=10$. Sedangkan nilai gain1, gain2, gain3 diperoleh dengan cara trial and error seperti yang dilakukan pada perancangan sistem pengendali FLC. Pada 


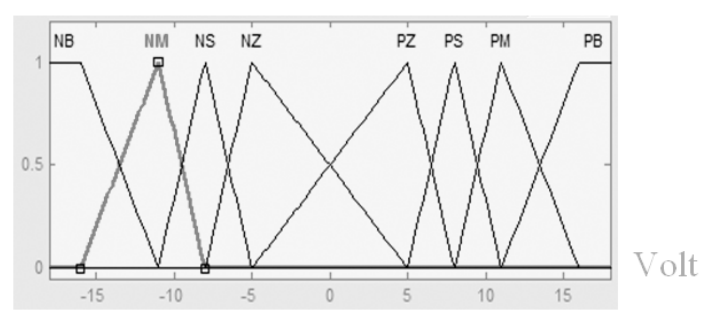

Gambar 7: Fungsi keanggotaan control input u pada pengendali FSMC

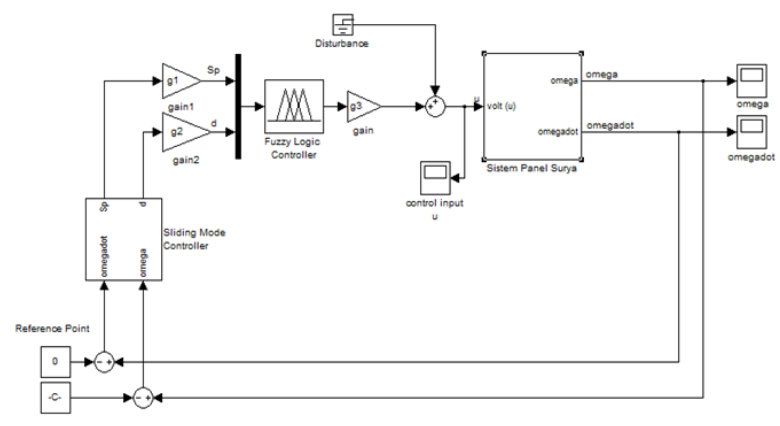

Gambar 8: Diagram blok sistem panel surya dengan pengendali FSMC

makalah ini diambil nilai - nilai gain untuk sistem pengendali FSMC yaitu $\mathrm{g} 1=0.0098, \mathrm{~g} 2=0.0025$, dan $\mathrm{g} 3=1$.

\section{Simulasi dan Analisa}

Pada bab ini dilakukan tiga macam simulasi, yaitu dengan tanpa gangguan, dan lainnya menggunakan dua gangguan yang berbeda, yaitu gangguan eksternal dan gangguan internal. Gangguan eksternal berasal dari luar sistem, sedangkan gangguan internal berupa gangguan dari dalam sistem. Hal ini dilakukan untuk menguji sifat robust sistem pengendali terhadap ketidakpastian dengan mengamati dan menganalisa performansi

Pada makalah ini akan diberikan nilai dari kecepatan sudut yang diinginkan $\omega=0.000073 \mathrm{rad} /$ detik dan percepatan sudut $\dot{\omega}=0$. Hal ini 
dimaksudkan bahwa nilai - nilai tersebut adalah default dan akan digunakan pada pengujian simulasi, baik dengan tanpa gangguan atau pun dengan gangguan.

\subsection{Simulasi Dengan Tanpa Gangguan}

Pada simulasi ini akan diberikan nilai - nilai parameter yang digunakan, yaitu $R_{a}=0.2, L_{a}=0.3, J=2, B=1, K_{b}=0.5$, dan $K_{m}=2$. Dari kondisi tersebut akan diperoleh hasil seperti pada Gambar 9.

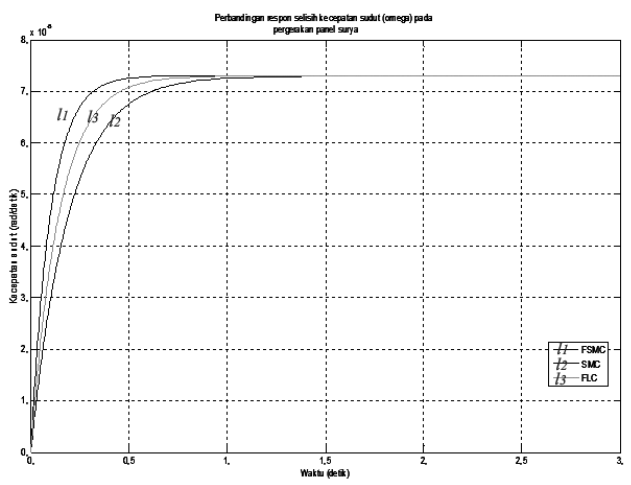

Gambar 9: Perbandingan respon $\omega$ (omega) pada pergerakan panel surya dengan tanpa gangguan

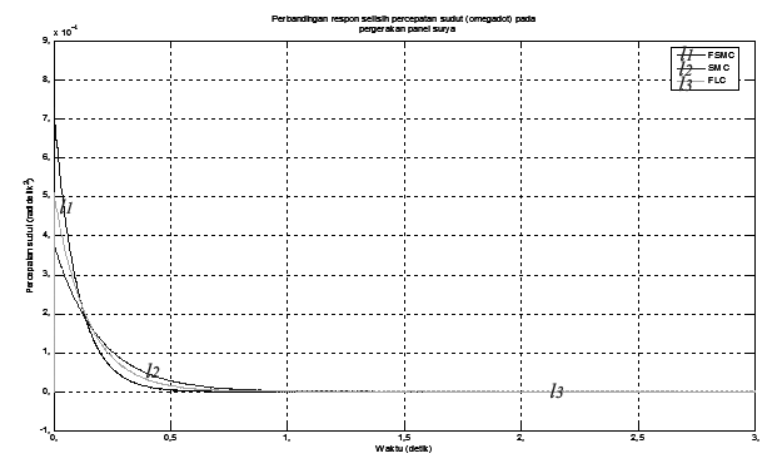

Gambar 10: Perbandingan $\dot{\omega}$ (omegadot) pada pergerakan panel surya dengan tanpa gangguan 
Pada kondisi tanpa gangguan tampak bahwa respon sistem pengendali FSMC lebih baik daripada pengendali FLC dan pengendali SMC karena waktu respon yang diberikan FSMC paling cepat dan menuju ke 0.000073. Grafik pada Gambar 9 dan Gambar 10 menggunakan nilai yang sama untuk FSMC dan SMC serta memiliki nilai control input yang sama pula pada FSMC dan FLC.

\subsection{Simulasi Dengan Gangguan Eksternal}

Simulasi ini dilakukan dengan menambahkan suatu sinyal yang dianggap sebagai gangguan yang berasal dari luar sistem. Sinyal yang akan ditambahkan pada simulasi ini diantaranya sinyal impuls dan square karena kedua sinyal tersebut memilki karakteristik yang berbeda yaitu impuls yang bersifat sesaat dan square yang bersifat kontinu pada selang waktu tertentu. Pada simulasi ini akan digunakan juga parameter - parameter yang sama dengan kondisi awal (default).

Sinyal impuls merupakan sinyal yang bernilai sangat besar dan muncul dalam waktu sangat singkat, sinyal ini mewakili gangguan dari luar yang bersifat sesaat. Dalam simulasi ini digunakan sinyal impuls yang benilai 0.9 Volt. Hasil yang diperoleh dari uji dengan sinyal ini adalah pada Gambar 11, pengendali FSMC bekerja lebih baik daripada pengendali SMC dan FLC. Pada gambar tersebut tampak adanya overshoot, namun overshoot yang terjadi masih bisa ditolerir karena nilai $\omega$ kurang dari $0.05 \mathrm{rad} /$ detik [5] dan keadaan tersebut tidak sampai merusak komponen - komponen dari sistem. Dengan demikian pengendali FSMC dikatakan cukup baik dalam menghadapi gangguan eksternal yang bersifat sesaat. Sedangkan pada sinyal square diberikan nilai square 0.9 Volt. Sinyal square adalah sinyal yang bernilai tetap untuk selang waktu tertentu. Hasil yang diperoleh tampak pada Gambar 12. Gambar 12 memperlihatkan bahwa sistem dengan gangguan square pun, pengendali FSMC bekerja lebih baik dari pada pengendali SMC dan FLC. Pada pengujian sinyal ganggual square ini, tampak juga adanya overshoot yang cukup besar, namun demikian overshoot yang terjadi masih dalam batas nilai toleransi. Dalam pengujian ini, FSMC dikatakan cukup baik dalam menghadapi gangguan eksternal yang bersifat kontinu. 


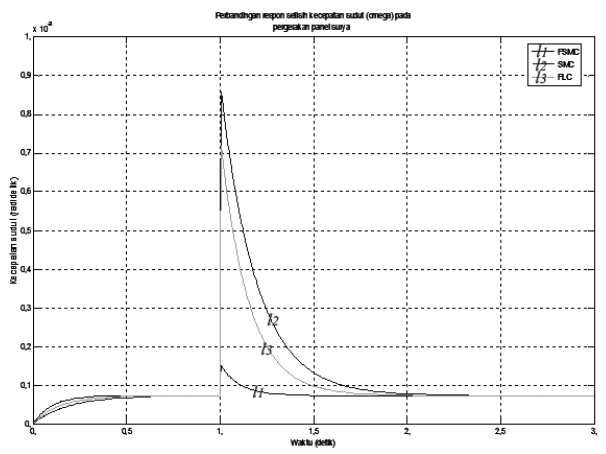

Gambar 11: Perbandingan respon $\omega$ (omega)pada pergerakan panel surya dengan sinyal impuls

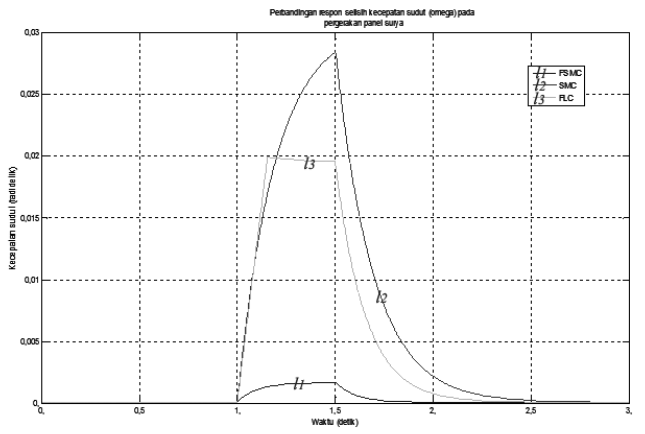

Gambar 12: Perbandingan respon $\omega$ (omega) pada pergerakan panel surya dengan sinyal square

\subsection{Simulasi Dengan Gangguan Internal}

Simulasi ini dilakukan dengan mengubah nilai parameter pada sistem panel surya untuk menguji kepekaan sistem terhadap ketidakpastian dari dalam sistem. Parameter yang diubah adalah hambatan, induktansi kumparan, momen inersia, koefisien gesek viskos, konstanta emf balik, dan konstanta torsi. Pengujian sistem pengendali terhadap gangguan internal ini dilakukan dengan memperkecil atau memperbesar nilai parameter. Dari Gambar 13 dan Gambar 14 dapat dilihat bahwa pengendali FSMC bekerja lebih baik pada gangguan internal daripada pengendali SMC dan FLC 
juga memiliki waktu respon yang lebih cepat. Hal ini dikarenakan oleh terbatasnya kemampuan SMC dan FLC dalam mengatasi ketidakpastian parameter. Pada dasarnya ketiga pengendali tersebut memiliki kemampuan yang hampir sama dalam mengatasi adanya overshoot. Itu tampak pada gambar bahwa tidak adanya overshoot pada ketiga pengendali tersebut, namun dalam hal ini FSMC memiliki sifat yang lebih robust.

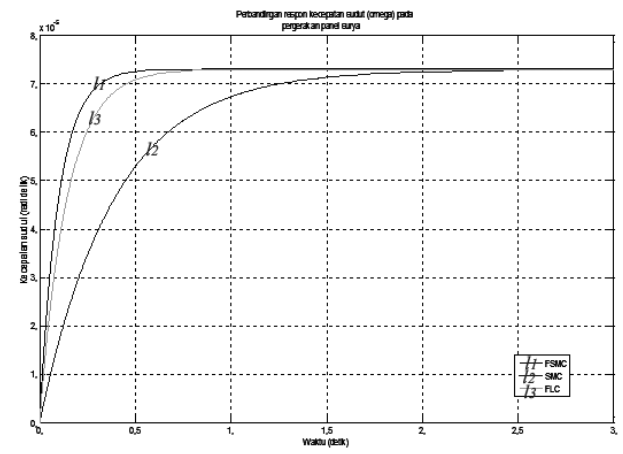

Gambar 13: Perbandingan respon $\omega$ (omega) pada pergerakan panel surya dengan parameter minimum

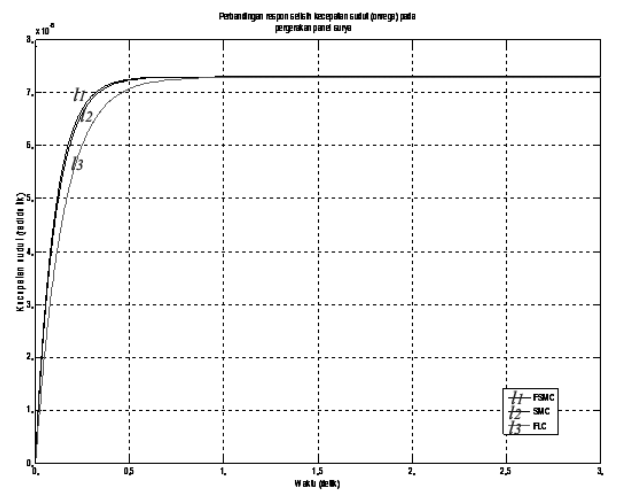

Gambar 14: Perbandingan respon $\omega$ (omega) pada pergerakan panel surya dengan parameter maximum 


\section{Kesimpulan}

Dari analisis dan pembahasan yang telah dilakukan pada sistem panel surya diperoleh kesimpulan bahwa :

1. Performansi sistem pengendali FSMC pada sistem panel surya memiliki beberapa kelebihan dibandingkan sistem pengendali SMC dan FLC, yaitu lebih robust terhadap berbagai gangguan baik eksternal maupun internal, lebih mudah dan sederhana dalam perancangannya, serta memiliki waktu respon lebih cepat.

2. Masih terdapat beberapa kekurangan yaitu membutuhkan penalaan gain agar logika fuzzy dapat mencapai performansi yang baik serta dapat bekerja dengan baik serta adanya overshoot pada pengujian gangguan yang bersifat eksternal, walaupun overshoot yang ada masih dapat ditolerir.

\section{Pustaka}

[1] Junaidi, M.A., Perancangan dan Simulasi Sistem Kontrol Posisi Pada Panel Surya dengan Menggunakan Metode Fuzzy Sliding Mode Control, Surabaya: Institut Teknologi Sepuluh Nopember, 2009.

[2] Kuo, C. B., Teknik Kontrol Automatik Jilid 1., Jakarta: Prenhallindo, 1998.

[3] Mintorogo, D.S., Strategi Aplikasi Sel Surya Photovoltaic Cells Pada Perumahan dan Bangunan Komersial, Surabaya: Universitas Kristen Petra, 2000.

[4] Musafa, A., Perancangan dan Simulasi Sistem Kontrol Posisi Pelacak Matahari Dengan Pengendali PID, Fakultas Teknik Universitas Budi Luhur, 2003.

[5] Ogata, K., Teknik Kontrol Automatik Edisi Kedua Jilid 1, Jakarta: Erlangga, 1996 
[6] Palm, R., Driankov, D., dan Hellendoorn, H., Model Based Fuzzy Control: Fuzzy Gain Schedulers and Sliding Mode Fuzzy Controllers, Berlin: Springer-Verlag, 1997.

[7] Perruquetti, W. dan Barbot, J.P., Sliding Mode Control in Engineering,New York: Marcel Dekker, Inc, 2002.

[8] Rizan, R.I., Analisis dan Perancangan Sistem Pengendali Pada Inverted Pendulum Menggunakan Metode Fuzzy Sliding Mode Control, Surabaya. Institut Teknologi Sepuluh Nopember, 2008.

[9] Zhang, H. dan Liu, D., Fuzzy Modeling and Fuzzy Control, Boston: Birkhuser, 2006.

[10] Zhu, F.Q.Q.M., Winfield, A., dan Melhuish, C., Fuzzy Sliding Mode Control for Discrete Nonlinear Sistems, Transactions of China Automation Society, Vol. 22, No. 2 (Sum No. 86), 2003. 